مقاله يخوهشى

مجله دانشگاه علوم يزشكى رفسنجان

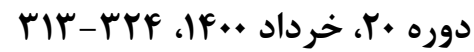

مقايسه اثربخشى حداقل و حداكثر دوز ينتوير ازول در درمان بيماران دجار زخم معده

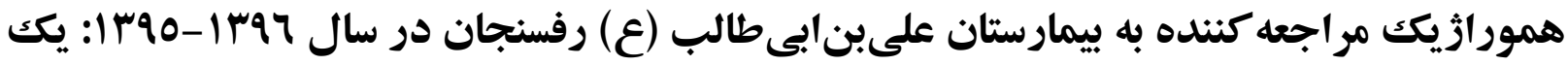
كار آزمايى بالينى تصادفى شده

عفت شهر آبادى '، حميد بخشى على آباد'، معصومه ميرانى رودبارى '، وحيد ميرزايىع

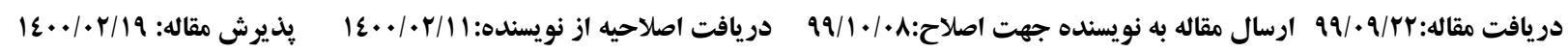

زمينه و هدف: مهاركنندههاى يمٍ يروتون نقش مهمـى در پايدار كردن لخته ايجاد شده ناشـى از خونريزى كوارشى فوقانى دارند. لذا اين مطالعه با هدف تعيين و مقايسه اثربخشى حداقل و حداكثر دوز ينتويرازول در درمان بيماران دجار زخهم

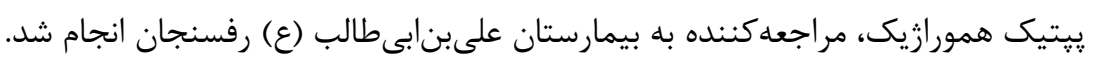
مواد و روشها: اين كارآزمايى بالينى تصادفى شده در سال ع9-هوبا در بيمارستان علىبنابىطالب (ع) رفسنجان بر روى ץ • ا بيمار مبتلا به خونريزى گوارشى فوقانى انجام شد. بيماران به صورت تصادفى به دو گروه مساوى تقسيم شدند: به كروه

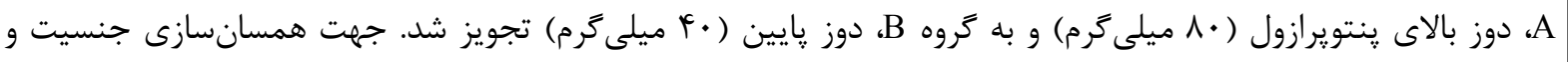

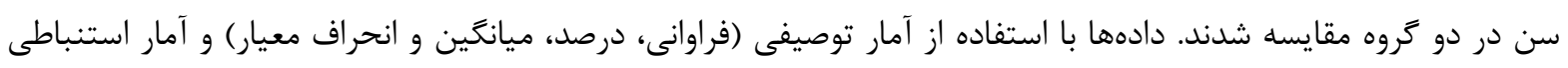

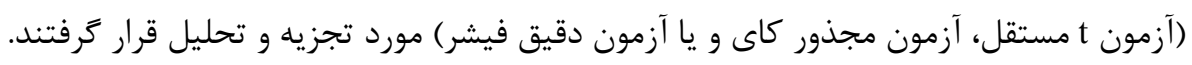
يافتهها: ميانگين و انحراف معيار سن بيماران در گروه A،

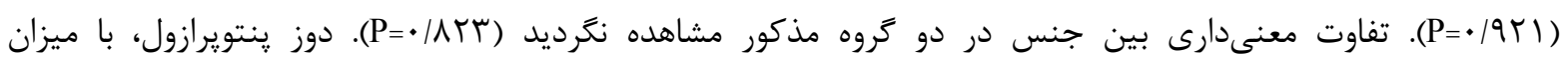

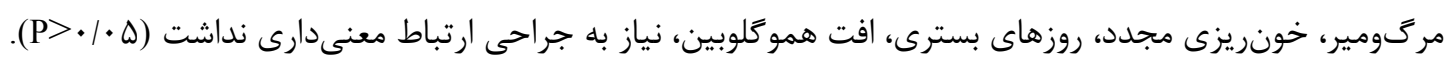

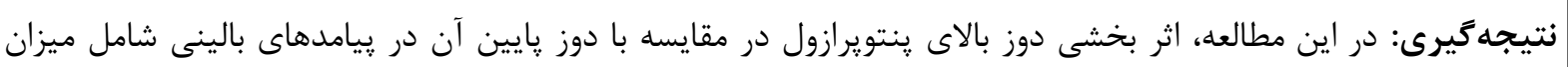

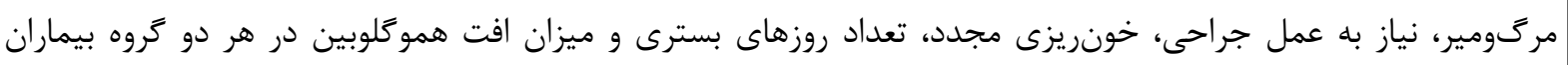

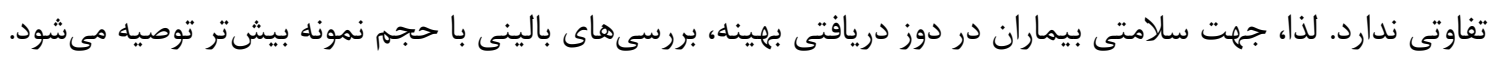

وازههاى كليدى: ينتويرازول، زخم معده همورازيك، خونريزى گوارشى فوقانى، زخم يِيتيك

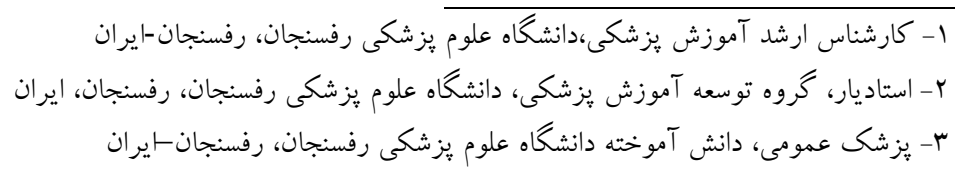

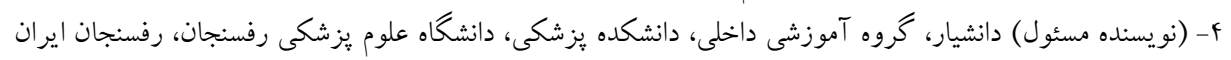

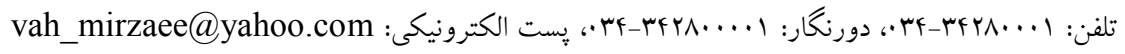


باشد [9]. خونريزى دستگاه گوارش فوقانى توسط

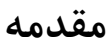

$$
\text { آندوسكويى مشخص مىشود [1]. }
$$

داروهايى كه براى درمان زخم معده مورد استفاده قرار مى

كيرد، داروهاى آنتىاسيد مانند هيدروكسيد منيزيوم و

آلومينيوم، كربنات كلسيم، بى كربنات سديم، و مهاركننده-

هاى يمٍ يروتون (Proton pump inhibitor; PPI) مانند:

ينتويرازول، رابيرازول، لانسويرازول، اميرازول، و H2 بلوكرها

مانند: رانيتيدين، سايمتيدين، نيزاتيدين، فاموتيدين و ورلتر

داروهايى مانند سوكرالفيت و بيسموت است [11]].

PPI از ميان داروهاى مذكور، در حال حاضر، اســفتاده از

مانند ينتويرازول نقش مهمــى در يايدار كردن لخته ايجاد

شده ناشــى از زخم يِيتيك دارد و باعث كاهش خونريزى

هاى بعدى و مرگ و مير در بيماران با زخم پر خطر بعد از

انجام اندوسكويى مى استفاده از PPI نسبت به بلوك كنندهاى گيرندهاى هيستامين را در كاهش عوارض خونريزى گوارشى گزارش كردهاند [ [ه-با1]. برترى داروهاى PPI نسبت به آنتاكونيستهاى گيرنده H2 به علت توانايى نحهداشتن pH

$[14,19]$

بعضى از يزوهشها كزارش نمودهاند كه نوع PPI تأثيرى در ييامد درمان ندارد [19-1 IV] و برترى انفوزيون مداوم دارو نســبت به دوزهاى تقسيم شده در مصرف PPI مورد تأييد قرار نكرفته است [•r، 11]. با توجه به تأثيرى كه PPI در كنترل خونريزىهاى دستگاه گوارش فوقانى دارد [rr-Ir]،
خونريزى دستگاه كوارش (Gastrointestinal bleeding) يكى از بيمارىهاى شايع دستگًاه گَارش است كه بستخى به محل آن به دو نوع خونريزى دستگاه گَارش فوقانى و تحتانى طبقهبندى شده است. به طورى كه خونريزى از مرى، معده و دئودنوم را خونريزى دستخاه گوارش فوقانى (1)] مىنامند [Upper gastrointestinal bleeding; UGIB) رايجترين علت UGIB زخم پֵֶتيك (Peptic ulcer) است و از فوريتهاى طب در سراسر دنيا محسوب مىشود [r]. حدوداً •ه درصد بيماران UGIB در بيمارستان بسترى مىشوند [1]، كه با هزينه بالاى درمانى مواجه مىشوند و در بعضى مواقع بيامد اين بيمارى منجر به مرگ بيماران مىشود [ب]. بعضى مطالعات ميزان مرگى مير را ه تا • ا درصد بيان نمودند كه با افزايش سن و همزمانى با بيمارى ديخر افزايش مىيابد [F]. در بعضى از بررسىها، بيان نمودهاند نزديك به نيمى از اين بيماران را قشر سالمند تشكيل مىدهد. كرجه • درصد اين خونريزىها خودبهخود قطع مى گردند اما در

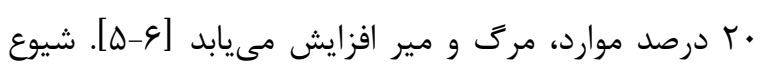
اين بيمارى در زنان و مردان يكسان بوده و با افزايش سن افزايش مىيابد [V]. بعضى از يزوهشها شيوع بيمارى در

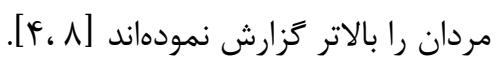
خونريزى دستخاه گَارش فوقانى با انواع مختلفى از علائم مانند هماتمز (Hematemesis)، ملنا (Melena)، هماتوشزيا (Hematochezia) شكم درد (Abdominal pain)، غش (Syncope) همراه مى 
تعداد مساوى تعيين مى در هر گروه له نفر و در مجموع \& • ا نفر تعيين گرديد. نمونهها از بخشهاى اورزانس و داخلى به شيوه نمونه حيرى آسان و بر اساس معيارهاى ورود انتخاب شدند. به اين منظور ابتدا بيماران با شكايت خونريزى گوارشى فوقانى با علائمى از قبيل هماتوشزى، ملنا، هماتمز، تحت آزمونهاى تشخيصى بيمارىها قرار گرفتند (اين آزمونها شامل آندوسكويى، آزمايش شمارش كلبولهاى خون Count) و انجام گرافىهاى تشخيصى شكمى بود). بنابراين، بيماران با تشخيص قطعى خونريزى گَوارشى فوقانى (زخم پِيتيك)، تحت معيارهاى ورود، وارد مطالعه شدند. بيمارانى كه علت مشخصى براى بيمارى آنها تشخيص داده مىشد از جمله واريس مرى، بدخيمىها، بدخيمىهاى ييش رونده، بيماران با درمان آنتى كوآكولانت (تحت درمان با وارفارين، ASA و NSAIDS) بيماران با مصرف ساير آنتىاسيدها (به غير از ينتويرازول)، افراد باردار،

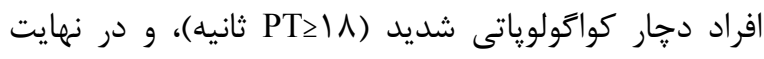
بيماران با عدم تمايل به شركت در مطالعه، تحت معيارهاى خروج از مطالعه حذف شدند.

به منظور رعايت ملاحظات اخلاقى در اين يزوهش، يس از تصويب (IR.RUMS.REC.1394.246)، هدف از مطالعه براى بيماران منتخب توضيح داده شده و رضايت آكاهانه اخذ كرديد.

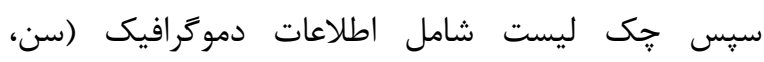

هنوز دوز مناسبى براى PPI تعيين نشده [بr] و در حال حاضر معمولاً PPI با دوز بالا براى بيماران استفاده مىشود. لذا، با توجه به اينكه مطالعات روشهاى اجرايى متفاوت و

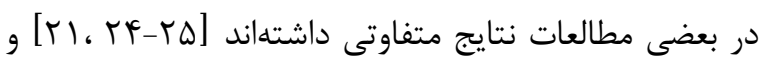
همجنين، در ايران تعداد معدودى يزوهش در اين زمينه انجام شده است [عr]، به اين منظور مطالعه حاضر با هدف تعيين و مقايسه اثربخشى حداقل و حداكثر دوز ينتويرازول در درمان بيماران دجار زخم پِيتيك همورازيك مراجعه كننده به بيمارستان علىبنابىطالب (ع) رفسنجان در سال عوبا |-

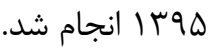

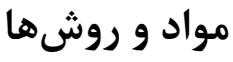

مطالعه حاضر يك كارآزمايى بالينى دوسوكور تصادفى شده است. جامعه آمارى شامل كليه بيماران مراجعه كننده به بيمارستان علىبنابى طالب (ع) رفسنجان در سال و9؟1 |هوسا با تشخيص خونريزى معده بود. در اين مطالعه، بر اساس اطلاعات مطالعه مشابه [عץ] و با استفاده از فرمول

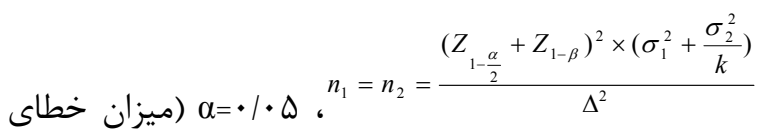

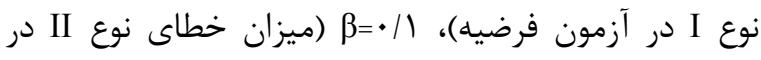

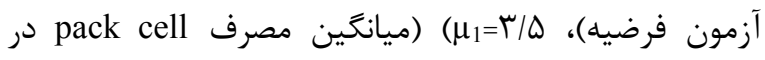

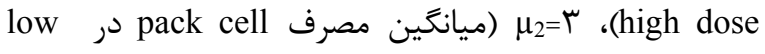
(dose)، = = (انحراف معيار ميزان مصرف در High dose)، ها $\sigma_{2}=1 /$ (انحراف معيار ميزان مصرف در low dose)،

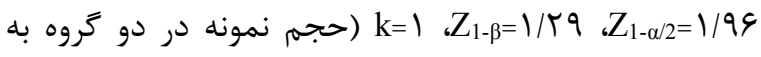


مى ينتويرازول دريافت مىكردند. اما اتر بيمار افت هموكلوبين نداشته و حال عمومى خوبى داشت و با شروع مصرف غذا، شكايتى از تهوع و استفراغ نداشت مىتوان كفت كه درمان موفقيتآميز بوده و مىتوان بيماران را VY ساعت بعد از PPI تزريقى و بدون داشتن علامتى با تجويز PPI دريافت بلهورت خوراكى مرخص كرد [rV]. در نهايت مرگومير، افت همو كلوبين بيش از ب واحد، خونريزى مجدد و نياز به جراحى و تعداد روزهاى بسترى در هر يك از خروهها و افرادى كه آندوسكويى آنها موفقيتآميز بوده و همرجنين از خونريزى در آنها جلوكيرى شده است بررسى و در جكليست مطالعه درج گرديد. تمامى بيماران مطالعه را به

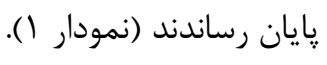

دادهها بعد از جمع آورى با نرمافزار SPSS تحت نسخه ب و با استفاده از روشهاى آمار توصيفى (فراوانى، درصد، ميانكين و انحراف معيار) و آمار استنباطى (آزمون مجذور كاى و يا آزمون دقيق فيشر) مورد تجزيه و تحليل قرار كرفت. در كليه آزمونهاى آمارى ه•/p معنىدارى در نظر كَرفته شد. ييش فرضهاى لازم براى آزمون مجذوركاى مورد بررسى قرار گرفت. در صورتى كه ·r درصد تعداد سلولهاى مورد انتظار جدول از ه بيشتر بود از آزمون نايارامتريك (آزمون دقيق فيشر) استفاده گرديد.
جنسيت، مدت زمان بسترى، خونريزى مجدد و ميزان افت هموكلوبين) توسط محقق با مصاحبه و قرائت شرح حال مندرج در يرونده يزشكى تكميل شد. بيماران به طور تصادفى ساده با استفاده از جدول تصادفى اعداد به دو گروه هr نفره (كروه A و گروه B ) تقسيم شدند. مطالعه بهصورت دوسوكور (عدم اطلاع بيمار و مسئول جمعآورى اطلاعات از

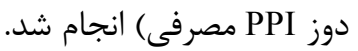
روش درمان بيمارى بدين طريق بود كه بيماران مراجعه كننده با علائم زخم كوارشى تحت آندوسكويى كه بخشى از درمان روتين است قرار گرفته، متخصصين برحسب نماى ظاهر ضايعه آندوسكويى، اقدامات درمانى را براى بيماران انجام مىدادند. به اينترتيب، بيمارانى كه زخمهاى با خطر بالا داشتند تحت درمان آندوسكويى به همراه تزريق داخل وريدى PPI قرار مى ₹رفتند. بنابراين، به بيماران گروه A، دوز بالاى ينتويرازول (•^ ميلى

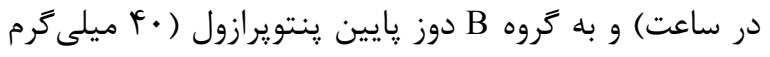
تكدوز بلصورت f ميلى Fرم در ساعت) تجويز شد [Y

اگر فرد دجار افت هموكلوبين، ملنا و استفراغهاى خونى شد، يعنى درمان موفقيتآميز نبوده و بيمار دجار خونريزى مجدد شده است كه در اين حالت آندوسكويى فورى انجام و در صورت تأييد خونريزى مجدد، اقدامات درمانى لازم انجام 


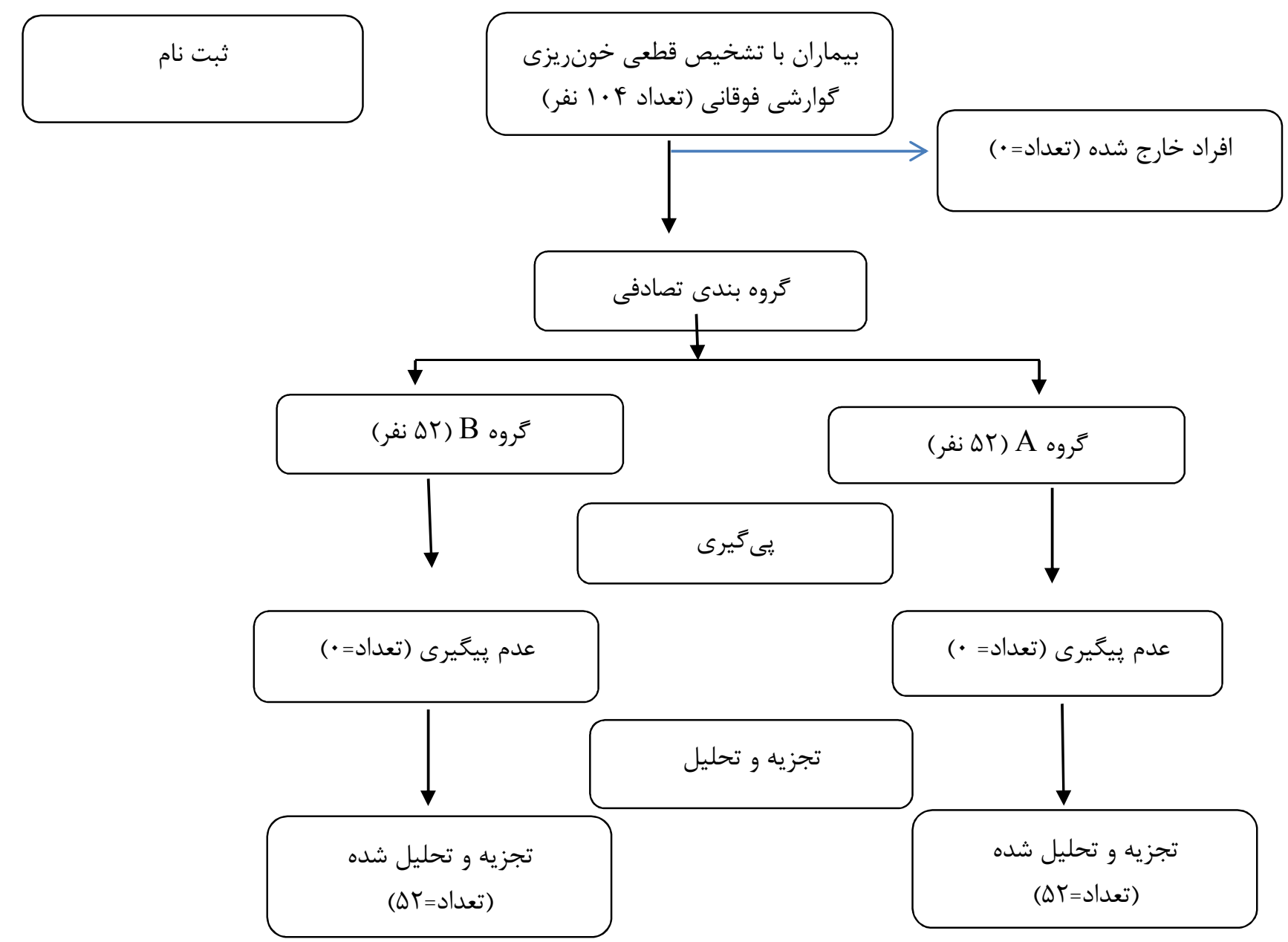

نمودار ا - فلوجارت كانسورت روند انتخاب، ارزيابى و يحكيرى بيماران با خونريزى كوارشى فوقانى مراجعه كننده به بيمارستان علىبن

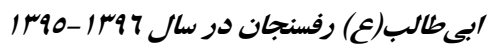

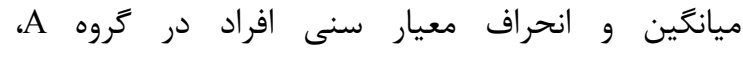

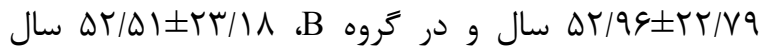
بود، از لحاظ سنى بين دو گروه تفاوت معنىدار آمارى مشاهده نشد (I (P=/9Y). همرجنين، تفاوت معنىدارى بين جنسيت زن و مرد در دو گروه مذكور مشاهده نكرديد

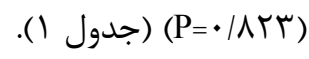

نتايج

نتايج مطالعه نشان داد كه از تعداد ع •ا بيمار مبتلا به

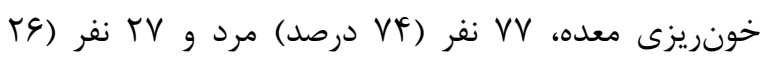
درصد) زن، با حداقل سن ها و حداكثر · ال سال بود. دامنه سنى بالاى •و سال، به تعداد أ| نفر (q/4 درصد) بيش ترين تعداد بيمار را شامل مىشد. در دو گروه Or نفره، 
1) اس مقايسه اثربخشى حداقل و حداكثر دوز ينتو يرازول در درمان بيماران ...

جلدول ا - برخى ويزٔسى هاى دموكرافيك بيماران دجار زخمر معلده همورازيك مراجعه كننده به بيمارستان على بنابى طالب(ع) رفسنجان برحسب كروههاى مورد بروسى در سال

\begin{tabular}{|c|c|c|c|c|c|c|}
\hline \multirow{3}{*}{ مقدار P P } & \multicolumn{4}{|c|}{ ميزان دوز PPI بر حسب ميلى } & \multirow{3}{*}{ سطوح متغير } & \multirow{3}{*}{ متغير } \\
\hline & \multicolumn{2}{|c|}{ تروه PPI ( } & \multicolumn{2}{|c|}{ كروه A (بالا) } & & \\
\hline & درصد & تعداد & درصد & ت تعداد & & \\
\hline \multirow{3}{*}{ " • } & $01 / 9$ & If & $Y N / 1$ & ir & 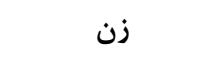 & \multirow{2}{*}{ جنسيت } \\
\hline & $r q / 4$ & ru & $\Delta \cdot 19$ & rq & مرد & \\
\hline & $F \Delta / \Lambda$ & 11 & $\Delta F / T$ & ir & كمتر از • سال & \\
\hline \multirow[t]{2}{*}{$" * / 9 T 1$} & YN/V & 19 & $\Delta 1 / r$ & $r$. & 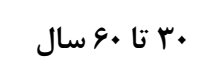 & سن (سال) \\
\hline & $\Delta r / V$ & rt & $\varphi \& / \pi$ & 19 & بيشتر از •ع سال & \\
\hline
\end{tabular}

جلدول r - توزيع فراوانى نوع بيامدهاي بالينى برحسب دومان PPI دو بيماران دجار زخم معلده همورازيك مراجعه كننده به بيمارستان علىبن

|بع طالب(ع) رفسنجان دو سال

\begin{tabular}{|c|c|c|c|c|c|c|}
\hline \multirow{3}{*}{ Pقدار P P P } & \multicolumn{4}{|c|}{ ميزان دوز PPI بر حسب ميلى ترم } & \multirow{3}{*}{ سطوح متغير } & \multirow{3}{*}{ متغير } \\
\hline & \multicolumn{2}{|c|}{ تروه PPI ( } & \multicolumn{2}{|c|}{ تروه API ( ) بالا) } & & \\
\hline & درصد & تعداد & درصد & تعداد & & \\
\hline \multirow{3}{*}{$\cdot / v a r^{*}$} & $\Delta$. & 1 & $\Delta$. & 1 & دارد & \multirow{3}{*}{ مركى و مير } \\
\hline & & & & & & \\
\hline & $\Delta \cdot$ & DI & $\Delta \cdot$ & QI & ن ارد & \\
\hline \multirow{2}{*}{$\cdot$ IVGV $^{* *}$} & $\varepsilon \& / r$ & 4 & $\Delta r / \Lambda$ & v & دارد & \multirow[b]{2}{*}{ 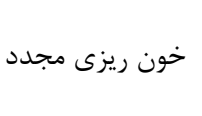 } \\
\hline & $\Delta \cdot / \Delta$ & 4q & $q q / \Delta$ & is & 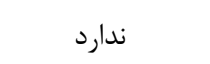 & \\
\hline \multirow{3}{*}{$\cdot / 94 \cdot{ }^{* *}$} & $\Delta \cdot 19$ & r. & $q q / q$ & rq & كمتر از F روز & \multirow{3}{*}{ 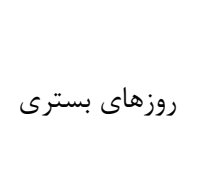 } \\
\hline & $\Delta \cdot$ & $\wedge$ & $\Delta \cdot$ & $\wedge$ & 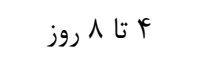 & \\
\hline & $k F / F$ & r & $\Delta Q / \varphi$ & $\Delta$ & بيشتر از ^ روز & \\
\hline \multirow{2}{*}{ ***/TTV } & $\Delta F / V$ & ra & $r \Delta / r$ & rq & كمتر از r واحد & \multirow{2}{*}{ افت هموكلوبين } \\
\hline & $q Y / D$ & iv & $\Delta V / \Delta$ & rr & بيشتر از ץ واحد & \\
\hline \multirow{3}{*}{ F**/VQ. } & $\varepsilon \Delta / \Delta$ & $\Delta$ & $\Delta F / \Delta$ & 4 & 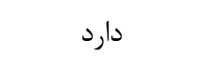 & \multirow{3}{*}{ نياز به جراحى } \\
\hline & & & & & & \\
\hline & $\Delta \cdot / \Delta$ & iv & $r q / \Delta$ & iq & ن ارد & \\
\hline
\end{tabular}

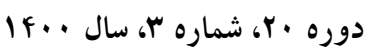

مجله دانشخاه علوم يزشكى رفسنجان 
Toosi داورى ينتويرازول با دوز بالا به دو روش تزريقى و خوراكى مورد مقايسه قرار داده بود ند تفاوتى از لحاظ مرگ و مير در دو گروه مشاهده ننمودند [^/r]. اين مطالعات با نتايج تحقيق حاضر همخوانى دارد. اما Worden و همكارش در بررسى بهينه سازى درمان با PPI براى درمان خونريزى دستگاه كوارش فوقانى بيان نمودند كه در درمان با PPI، ميزان مرى و مير به طور قوى مشخص نشده است [9r]. به نظر مىرسد، بهدليل معدود مطالعات در خصوص دوز بالاو يايين تزريقى در بيماران با خونريزى معده و از طرفى تفاوت در روش اجراى تحقيقات باعث ناهمگونى مىشود. به طورى كه بعضى از مطالعات تأثير دوز دارو را بر بيماران و گروه كنترل از قبيل دارونما و غيره [•r] و بعضى نيز دو گروه يرخطر بيماران را با دوزهاى بالا ينتويرازول تزريقى و خوراكى مورد

بررسى قرار دادند [ [اس].

نتايج مطالعه حاضر نشان داد كه ميزان نياز به عمل جراحى و خونريزى مجدد و همجنين ميانگين روزهاى بسترى در هر دو گروه بيماران تحت درمان با دوز بالا و ״ايين زينتويرازول مشابه بوده و اين افزايش يا كاهش ينتويرازول تأثيرى بر متغيرهاى ياد شده نداشت. Sgourakis و همكارانش در مطالعه مرورى سيستماتيك دوز بالا و پايين وريدى را در بيماران مبتلا به خونريزى زخم معده PPI انجام دادند. نتايج نشان داد كه نياز به عمل جراحى و خون ريزى مجدد در هر دو كروه يكسان است [זr]. همرجنين، Motiei در ميزان خونريزى مجدد، مدت بسترى در هر دو دوز PPI مصرفى يكسان است [آ]]. اما در اين خصوص Leontiadis
نتايج جدول r، نشان مىدهد كه تعداد افراد با دوز دريافتى به مقدار بالا (•^ ميلى (•رم تكدوز بهصورت ^ ميلى PPI

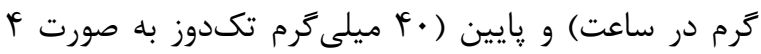
ميلى مجدد بيشتر از تعداد افراد دجار مرگ و مير و خونريزى بودند. همجنين، تعداد افراد بسترى كمتر از أ روز بيشتر از تعداد افراد بسترى \& روز و بالاتر و تعداد افرادى كه نياز به جراحى نداشتند، بيشتر از تعداد افراد نياز به جراحى بود. PPI افت هموكلوبين كمتر از دو واحد، با ميزان دوز دريافتى بالا، بيشتر از دوز پايين بود. اما تفاوتها از نظر آمارى

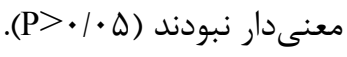
بحث يزوهش حاضر با هدف مقايسه اثربخشى حداقل و حداكثر دوز ينتويرازول در درمان بيماران مراجعه كننده با زخم معده همورازيك به بيمارستان علىبنابىطالب (ع) رفسنجان در

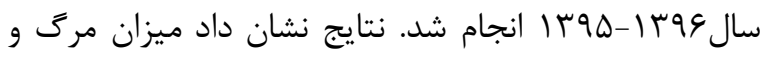
مير ناشى از خونريزى در بيماران درمان شده با دوز بالا و קايين PPI تفاوت معنى Pasjedizadeh و و ندارى همكارانش نيز در يك مطالعه كارآزمايى بالينى دوسوكور، دوز ينتويرازول بالا و پايين را بر روى دو گروه از بيماران با زخمهاى يرخطر يֶتيك مورد بررسى قرار داده، بيان نمودند كه دوز مصرفى بر روى مرى و مير بيماران در دو گروه تأثيرى نداشت [عr]. در مطالعه Motiei و همكارش كه اثر بخشى دوز بالا و پايين ينتويرازول بر روى بيماران خون ريزى معده بررسى نمودند، نشان داد كه مقدار دوز مصرفى

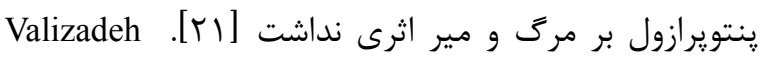


• • .

جراحى در اين بيماران و دوز مناسب دارو كه از نظر اقتصادى نيز اهميت زيادى در مقرون به صرفه بودن آن براى بيمار و مراكز درمانى دارد، دست يافت.

\section{نتيجه تيرى}

يافتههاى مطالعه حاضر نشان داد پيامدهاى بالينى در درمان با دوزهاى بالا و پايين رِنتويرازول در بيماران با زخم معده همورازيك، شامل ميزان مرك و مير، نياز به عمل جراحى، خونريزى مجدد، روزهاى بسترى و ميزان افت هموگلوبين در هر دو گروه تفاوت معنى دارى ندارد. با توجه به نتايج مطالعه اخير، مىتوان از دوز پايين ينتويرازول نيز جهت بيماران استفاده نمود. اما اين موضوع نياز به مطالعات بيشتر با حجم نمونه بالاتر دارد تا بتوان جهت سلامتى بيماران تصميمكيرىهاى لازم جهت دوز مناسب و بهينه

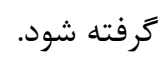

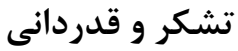

اين مقاله حاصل پايانامه مصوب دانشكاه علوم يزشكى

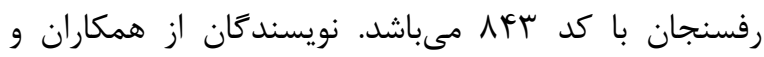

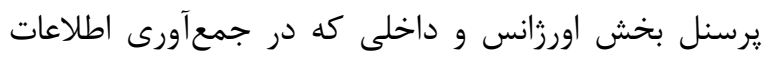

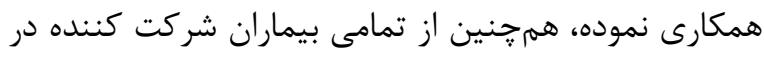

$$
\text { اين يزوهش، تشكر مىنمايند. }
$$

و همكارانش در مطالعه بيان نمودند كه PPI بالا، خونريزى مجدد و طول مدت بسترى را به طور معنىدارى كاهش مىدهد [ [rr]. همرجنين، از آنجايى كه يزوهش مطالعات كاملاً مشابه با يززوهش اخير را از طريق جستجو در منابع קֶيدا ننمودند، به نظر مىرسد، اين تفاوتها به دليل حجم نمونهها و روشهاى اجرايى مختلفى است كه در مطالعات مورد استفاده قرار كرفته است. در بخشى از تحقيق حاضر، به بررسى ميانگَن افت همو كلوبين در بيماران درمان شده با تجويز دوز بالا و دوز يايين PPI يرداخته شد. نتايج نشان داد دوز PPI با ميزان افت همو حلوبين ارتباط نداشت. مطالعه Masjedizadeh و همكارانش نيز با مطالعه حاضر همخوانى دارد [عب]. از محدوديت هاى مطالعه، pH معده اندازهيرى نشده است. بنابراين، نمىتوان نتيجه كَفت كه هر دو روش در كاهش و كنترل اسيد مشابه هستند. با اين حال، بايد توجه داشت كه هر دو روش تأثيرى در كنترل اسيد دارند، اما نتيجه تحقيق را تغيير نمىدهد. زيرا اثر دارو در حال بررسى بود. پيشنهاد مىشود مطالعهاى با حجم نمونه بزرگتر و همجنين با دوزهاى متفاوت ينتويرازول و يا ساير داروهاى مشابه در اين زمينه طراحى شود تا بتوان به راهكارهايى جهت كاهش مرى و مير و خونريزى مجدد و نياز به

\section{References}

[1] Jameson LLKasper D, Longo DL, Fauci AS, Hauser SL, Loscalzo J. Harrisons Principles of Internal Medicine. $20^{\text {th }}$ Edition ed: USA: McGraw-Hill Education; 2018; $2177-82$ 
[2] Nelms DW, Pelaez CA. The acute upper gastrointestinal bleed. Surg Clin North Am 2018; 98(5): 1047-57.

[3] Naseer M, Lambert K, Hamed A, Ali E. Endoscopic advances in the management of non-variceal upper gastrointestinal bleeding: A review. World $J$ Gastrointest Endosc 2020; 12(1): 1-16.

[4] Budimir I, Stojsavljević S, Hrabar D, Kralj D, Bišćanin A, Kirigin LS, et al. Bleeding Peptic Ulcer - Tertiary Center Experience: Epidemiology, Treatment and Prognosis. Acta Clin Croat 2017; 56(4): 707-14.

[5] Keshavarz AA, Rezvanfar HA. Acute Upper Gastrointestinal Bleeding Course in Patients over \& under the Age 60. Journal of Kermanshah University of Medical Sciences 2007; 11(3): 277-85.

[6] Felman M, Friedman L, Brandt L. Sleisenger and Fordtran's Gastrointestinal and liver disease. 11thEd ed2020. 720-820.

[7] [Ebrahimi Daryani, Foroogh A. treatment of nonvaricose upper gastrointestinal bleeding. Scient Jou of the Med Sys Organ of the Islamic Rep of Iran 2014; 33(4): 341-6.
[8] Masoodi M, Saberifiroozi M. Etiology and outcome of acute gastrointestinal bleeding in iran: a review article. Middle East J Dig Dis. 2012; 4(4): 193-8.

[9] Thiebaud P-C, Yordanov Y, Galimard J-E, Raynal P-A, Beaune S, Jacquin L, et al. Management of upper gastrointestinal bleeding in emergency departments, from bleeding symptoms to diagnosis: a prospective, multicenter, observational study. Scandinavian Journal of Trauma, Resuscitation and Emergency Medicine 2017; 25(1): 78 .

[10] Wilkins T, Wheeler B, Carpenter M. Upper Gastrointestinal Bleeding in Adults: Evaluation and Management. Am Fam Physician. 2020; 101(5): 294300.

[11] Jiang M, Chen P, Gao Q. Systematic Review and NetWork Meta-Analysis of Upper Gastrointestinal Hemorrhage Interventions. Cell Physiol Biochem 2016; 39(6): 2477-91.

[12] Rensburg V, Cheer S. Pantoprazole for the Treatment of peptic Ulcer Bleeding and prevention of Rebleeding. van Rensburg and Cheer52Clinical Medicine insights: Gastroenterology 2012; 5: 51-60.

[13] Malfertheiner P, Chan FK, McColl KE. Peptic ulcer disease. The lancet 2009; 374(9699): 1449-61. 
[14] Kang SH, Yim HJ, Kim SY, Suh SJ, Hyun JJ, Jung SW, et al. Proton Pump Inhibitor Therapy Is Associated With Reduction of Early Bleeding Risk After Prophylactic Endoscopic Variceal Band Ligation: A Retrospective Cohort Study. Medicine (Baltimore) 2016; 95(8): e2903.

[15] Ravisankar P, Koushik O, Reddy A, KumarU AP, Pragna P. A Detailed Analysis on Acidity and Ulcers in Esophagus, Gastric and Duodenal Ulcers and Management. IOSR Journal of Dental and Medical Sciences (IOSR-JDMS). 2016; 15(1): 94-114.

[16] Scarpignato C, Gatta L, Zullo A, Blandizzi C, Scarpignato C, Blandizzi C, et al. Effective and safe proton pump inhibitor therapy in acid-related diseases - A position paper addressing benefits and potential harms of acid suppression. BMC Medicine 2016; 14(1): 179.

[17] Hung WK, Li VK, Chung CK, Ying MW, Loo CK, Liu CK, et al. Randomized trial comparing pantoprazole infusion, bolus and no treatment on gastric $\mathrm{pH}$ and recurrent bleeding in peptic ulcers. ANZ J Surg 2007; 77(8): 677-81.

[18] Tsoi K, Hirai H, Sung J. Meta-analysis: comparison of oral vs. intravenous proton pump inhibitors in patients with peptic ulcer bleeding. Alimentary pharmacology \& therapeutics $2013 ; 38(7): 721-8$.

[19] Javid G, Zargar SA, Seif RU, Khan BA, Yatoo GN, Shah AH, et al. Comparison of p.o. or i.v. proton pump inhibitors on 72-h intragastric $\mathrm{pH}$ in bleeding peptic ulcer. J Gastroenterol Hepatol 2009; 24(7): $1236-43$.

[20] Sachar H, Vaidya K, Laine L. Intermittent vs continuous proton pump inhibitor therapy for highrisk bleeding ulcers: a systematic review and metaanalysis. JAMA Intern Med 2014; 174(11): 1755-62.

[21] Motiei A, Sebghatolahi V. Efficacy Comparison of Divided and Infusion Intravenous Pantoprazole Methods after Endoscopic Therapy in Patients with Acute Gastrointestinal Bleeding. Adv Biomed Res 2017; 6: 120 .

[22] van Rensburg CJ, Cheer S. Pantoprazole for the treatment of peptic ulcer bleeding and prevention of rebleeding. Clin Med Insights Gastroenterol 2012; 5: $51-60$.

[23] Leontiadis GI, Howden CW, Barkun AN. High-dose versus low-dose intravenous proton pump inhibitor treatment for bleeding peptic ulcers. Expert Review of Gastroenterology \& Hepatology 2012; 6(6): 675-7. 
[24] Zhang YS, Li Q, He BS, Liu R, Li ZJ. Proton pump inhibitors therapy vs $\mathrm{H} 2$ receptor antagonists therapy for upper gastrointestinal bleeding after endoscopy: A meta-analysis. World J Gastroenterol 2015; 21(20): $6341-51$

[25] Krag M, Marker S, Perner A, Wetterslev J, Wise MP, Schefold JC, et al. Pantoprazole in Patients at Risk for Gastrointestinal Bleeding in the ICU. $N$ Engl J Med 2018; 379(23): 2199-208.

[26] Masjedizadeh AR, Hajiani E, Alavinejad P, Hashemi SJ, Shayesteh AA, Jamshidian N. High Dose versus Low Dose Intravenous Pantoprazole in Bleeding Peptic Ulcer: A Randomized Clinical Trial. Middle East J Dig Dis 2014; 6(3): 137-43.

[27] Office of Standardization and Development of Clinical Guidelines. Clinical guidlineClinical for the Management of Upper Gastrointestinal Bleeding Treatment Order: Standardization and Clinical Guidelines Office. 2015:82.

[28] Valizadeh Toosi SM, Elahi Vahed AR, Maleki I, Bari Z. Comparison of Oral versus Intravenous Proton Pump Inhibitors in Preventing Re-bleeding from Peptic Ulcer after Successful Endoscopic Therapy. Middle East J Dig Dis 2018; 10(4): 236-41.
[29] Worden JC, Hanna KS. Optimizing proton pump inhibitor therapy for treatment of nonvariceal upper gastrointestinal bleeding. Am J Health Syst Pharm 2017; 74(3): 109-16.

[30] Moayyedi P, Eikelboom JW, Bosch J, Connolly SJ, Dyal L, Shestakovska O, et al. Pantoprazole to Prevent Gastroduodenal Events in Patients Receiving Rivaroxaban and/or Aspirin in a Randomized, Double-Blind, Placebo-Controlled Trial. Gastroenterology 2019; 157(2): 403-12.

[31] Karim R, Hameed R, Ali K, Tahir A. Comparison of Oral versus Intravenous Proton Pump Inhibitors in Preventing Re-bleeding from Peptic Ulcer after Successful Endoscopic Therapy. Cureus 2020; 12(1): e6741.

[32] Sgourakis G, Chatzidakis G, Poulou A, Malliou P, Argyropoulos T, Ravanis G, et al. High-dose vs. Lowdose Proton Pump Inhibitors post-endoscopic hemostasis in patients with bleeding peptic ulcer. A meta-analysis and meta-regression analysis. Turk $J$ Gastroenterol 2018; 29(1): 22-31. 


\title{
Comparison of Effectiveness of Minimum and Maximum Dose of Pantoprazole in the Treatment of Patients with Hemorrhagic Gastric Ulcer Referred to Ali-Ebn Abitaleb Hospital in Rafsanjan in 2016-2017: A Randomized Clinical Trial
}

\author{
E. Shahrabadi', H. Bakhshi Aliabad ${ }^{2}$, M. Mirani Roudbari ${ }^{3},{\underline{\text { V. } \text { Mirzaee }^{4}}}^{4}$ \\ Received:12/12/20 Sent for Revision: 28/12/20 Received Revised Manuscript:01/05/21 Accepted:09/05/21p
}

Background and Objectives: Proton pump inhibitors (PPIs) have an important role in stabilizing clots caused by upper gastrointestinal bleeding. The aim of this study was performed to compare and determine the effectiveness of the minimum and maximum dose of pantoprazole in the treatment of patients with hemorrhagic gastric peptic ulcer, referred to Rafsanjan Ali ebn Abitaleb Hospital.

Materials and Methods: This randomized clinical trial was performed on 104 patients with upper gastrointestinal bleeding in Rafsanjan Ali ebn Abitaleb Hospital in 2016-2017. Patients were randomly divided into two equal groups. Group A was given a high dose of pantoprazole $(80 \mathrm{mg})$ and group B was given a low dose $(40 \mathrm{mg})$. For gender and age matching, the two groups were compared ( $\mathrm{p}>0.05)$. Data were analyzed using descriptive statistics (frequency, percentage, mean and standard deviation) and inferential statistics (independent t-test, chi-square test or Fisher's exact test).

Results: The mean and standard deviation of patients' age in group A were $52.96 \pm 22.79$ years and in group B 52.51 \pm 23.18 years $(p=0.921)$. No significant difference was observed between the sexes in the two groups ( $p=0.823)$. PPI dose was not significantly associated with mortality rate, hemorrhage, hospitalization days, drop in hemoglobin, need for surgery $(\mathrm{p}>0.05)$.

Conclusion: In this study, the efficacy of high-dose pantoprazole compared with low-dose in clinical outcomes including mortality, need for surgery, hemorrhage, number of hospitalization days, and hemoglobin drop did not differ between the two groups. Therefore, for the health of patients at the optimal dose, clinical studies with a larger sample size are recommended.

Key words: Pantoprazole, Hemorrhagic gastric ulcer, Upper gastrointestinal bleeding, Peptic ulcer

Funding: This study did not have any funds.

Conflict of interest: None declared.

Ethical approval: The Ethics Committee of Rafsanjan University of Medical Sciences approved the study (IR.RUMS.REC.1394.246).

How to cite this article: Shahrabadi E, Bakhshi Aliabad H, Mirani Roudbari M, Mirzaei V. Comparison of Effectiveness of Minimum and Maximum Dose of Pantoprazole in the Treatment of Patients with Hemorrhagic Gastric Ulcer Referred to Ali-Ebn Abitaleb Hospital in Rafsanjan in 2016-2017: A Randomized Clinical Trial. J Rafsanjan Univ Med Sci 2021 ; 20 (3): $313-24$. [Farsi]

1-MSc in Medical Education, Rafsanjan University of Medical Sciences, Rafsanjan Iran, ORCID: 0000-0003-3965-4688

2- Assistant Prof., Dept. of Medical Educational Devlopment, Rafsanjan University of Medical Sciences, Rafsanjan,Iran, ORCID: 0000-00022257-8378

3- General Practitioner, Graduate of Rafsanjan University of Medical Sciences, Rafsanjan, Iran, ORCID: 0000-0002-8236-9957

4 Associate Prof., Dept. of Internal Medicine, School of Medicine, Rafsanjan University of Medical Sciences, Rafsanjan, Iran, ORCID: 0000-003-0179-9224

(Corresponding Author) Tel: (034) 34280001, Fax: (034) 34280001, E-mail:vah_mirzaee@yahoo.com

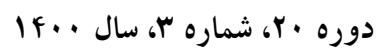

مجله دانشگاه علوم يزشكى رفسنجان 